\title{
Telomere Biology and Thoracic Aortic Aneurysm
}

\author{
Thomas Aschacher ${ }^{1, *}$ (1), Olivia Salameh ${ }^{2}$ (1), Florian Enzmann ${ }^{3}$, Barbara Messner ${ }^{1}$ \\ and Michael Bergmann 4,5 \\ 1 Cardiac Surgery Research Laboratory, Department of Surgery, Medical University of Vienna, \\ Waehringer Guertel 18-20, 1090 Vienna, Austria; barbara.messner@meduniwien.ac.at \\ 2 Plastic and Reconstructive Surgery, Department of Surgery, Medical University of Vienna, \\ Waehringer Guertel 18-20, 1090 Vienna, Austria; olivia.salameh@meduniwien.ac.at \\ 3 Department of Vascular and Endovascular Surgery, Paracelsius Medical University, \\ Muellner Hauptstrasse 48, 5020 Salzburg, Austria; fkenzmann@gmail.com \\ 4 Surgical Research Laboratories, Department of Surgery, Medical University of Vienna, \\ Waehringer Guertel 18-20, 1090 Vienna, Austria; michael.bergmann@meduniwien.ac.at \\ 5 Comprehensive Cancer Centre, 1090 Vienna, Austria \\ * Correspondence: thomas.aschacher@meduniwien.ac.at; Tel.: +43-1-40400-69690
}

Received: 1 October 2017; Accepted: 19 December 2017; Published: 21 December 2017

\begin{abstract}
Ascending aortic aneurysms are mostly asymptomatic and present a great risk of aortic dissection or perforation. Consequently, ascending aortic aneurysms are a source of lethality with increased age. Biological aging results in progressive attrition of telomeres, which are the repetitive DNA sequences at the end of chromosomes. These telomeres play an important role in protection of genomic DNA from end-to-end fusions. Telomere maintenance and telomere attrition-associated senescence of endothelial and smooth muscle cells have been indicated to be part of the pathogenesis of degenerative vascular diseases. This systematic review provides an overview of telomeres, telomere-associated proteins and telomerase to the formation and progression of aneurysms of the thoracic ascending aorta. A better understanding of telomere regulation in the vascular pathology might provide new therapeutic approaches. Measurements of telomere length and telomerase activity could be potential prognostic biomarkers for increased risk of death in elderly patients suffering from an aortic aneurysm.
\end{abstract}

Keywords: telomeres; telomere maintenance mechanism; telomerase; aging; aortic aneurysm

\section{Introduction}

Telomeres are tandem DNA repeat sequences at the end of chromosomes, which maintain genomic stability during cell divisions [1-3]. Unfortunately, telomere length (TL) shortens with every cell replication. This results in the DNA polymerase inability to precisely replicate the set of chromosomes $[4,5]$. The "end replication problem" results in the critical shortening of TL or instability of the telomeric binding proteins (TBPs). This induces an arrest of cell division or a replicative senescence [6-9], which may cause genomic instability. On average, cells reach senescence after approximately 50 divisions. TL can reflect cellular turnover and is therefore used as a surrogate marker for age and as a feasible biomarker for age-related diseases. These include cardiovascular diseases and infections, which are proven to have accelerated telomere shortening [10]. TL has its potential prognostic value related to marking the specific stages of disease progression. Despite the value of maintaining TL, a limited number of cells, especially in cells with a high turnover (e.g., tumor and epithelial cells) are able to reactivate the enzyme telomerase. Telomerase, a reverse transcriptase enzyme, adds repeat sequences to the end of chromosomes [7,11]. This ensures prolonged cell survival and extended proliferation $[3,5]$. Moreover, telomerase presents extra-telomeric functions of enhancing 
cell repair mechanisms and stress resistance, as well as down-regulation of apoptotic effectors. Seen as a whole, it is clear that telomerase functions support DNA stability [12-14].

Aortic aneurysms are characterized by local inflammation with degeneration around the aorta, which leads to weakening and widening of the vessel. The formation of aortic aneurysms can be congenital or acquired and occur at different locations of the thoracic or abdominal wall. Abdominal aortic aneurysms (AAA) are strongly associated with arteriosclerosis and inflammation [15], while thoracic aortic aneurysms (TAA) are consequences of degenerative processes, hypertension or genetic mutations in rare disorders (Ehlers-Danlos or Loeys-Dietz Syndrome) [16,17]. The findings of Morgen et al. demonstrate that advancing age is associated with telomere uncapping in arteries, which is linked to senescence, which occurs independently of telomere shortening [18]. While it has been confirmed that chronic inflammation in AAA plays a crucial role of aneurysm formation, the TAA pathway still has to be discussed and requires further research.

Vascular aging involves senescence of endothelial cells (EC) and vascular smooth muscle cells (vSMC), which can be caused by telomere shortening. Several studies have shown an association of the reduction of TL in blood cells with several vascular diseases [19-24]. A major vascular disease affecting the aorta is the sporadic thoracic aortic aneurysm, which has particularly increased incidence in the elderly population $[16,25,26]$.

The aim of this review is to summarize the role of TL and maintenance by telomerase in vascular diseases of the thoracic ascending aorta. We discussed the results and main conclusions that have identified shorter TL as a primary abnormality in the pathogenesis $[27,28]$ and the influence of telomere function on the risk of vascular diseases.

\section{Telomeres: Structure, Functions and Maintenance}

The main function of telomeres is to protect the end of chromosomes during replication. This is essential for protecting the integrity of genomic material. Thus, complete replication of linear DNA molecules is not possible, which was originally proposed as the "end replication problem", by James Watson and Alexey Olovnikov $[29,30]$ in the early 1970s. The removal of the terminal RNA primer on the lagging strand leaves an un-replicated gap, resulting in loss of terminal sequences and genomic instability. The ability of telomeres to safeguard genomic material is enabled by the dynamic structure of telomeres and TBPs. Human telomeres contain repeats of sequence $3^{\prime}$-CCCTAA $/ 5^{\prime}$-TTAGGG that have 2-50 kilobase pairs and a G-tail of 100-250 bases detected throughout the cell cycle [31-33]. However, the "Shelterin complex" contains up to six core components. These are telomere repeat binding factor 1 and 2 (TRF1 and TRF2), TRF1 interacting nuclear factor 2 (TIN2), protector of telomeres 1 (POT1), repressor/activator protein 1 (RAP1) and tripeptityl-peptidase 1(TPP1), whereby three of these factors are associated directly with the telomeric DNA either in its single stranded (ss) (POT1) or double stranded (ds) (TRF1, TRF2) form. These components play an essential role in telomere protection and telomerase regulation [33]. The Shelterin complexes selectively bind with high affinity to areas of the telomere where ss/ds-DNA junctions carry POT1 and TRF1 or TRF2, such as the $3^{\prime}$-telomeric end [34]. Telomeric zinc finger-associated protein (TZAP), a specific telomere-associated protein, binds to long telomeres with low concentrations of Shelterin complex by competing with TRF1 and TRF2. The TZAP binding triggers telomere trimming, which is an additional mechanism of TL control [35]. However, depletion of TRF2 induces chromosome end-to-end fusions, which result in loss of telomeric sequences and consequently leads to critical telomere shortening found in human cancer and cells [36].

Telomere-associated proteins influence the control of TL and DNA damage, which involves: (i) proteins acting as activators of the Wnt signaling pathway; (ii) modulating Ataxia-telangiectasia mutated kinase (ATM)-dependent Ataxia telangiectasia and Rad3-related protein (ATR), which is activated in response to damaged caused by DNA-double strand breaks (DSB) [37]; and (iii) poly-ADP ribose polymerase-1 (PARP-1), which is important for the normal or abnormal recovery of DNA damage [38]. In particular, TRF1 and TRF2 can be modified and regulated by PARP enzymes [39,40]. 
Telomere homeostasis involves different factors that are involved in telomere shortening or attrition and maintaining TL. A new technique developed in the Mai Laboratory in Winnipeg allows the detection of telomere anomalies (attrition, aggregates) in 3D [41,42]. Telomere shortening is posed by telomere attrition during cell division or direct DNA damage on telomeric sequences. Telomeric DNA damage can be caused by oxidative stress, loss or deficiency of TSB or degradation of RNA primers of proteins involved in DNA repair (e.g., Ku 70/80, PARP-1). In addition, homeostasis of telomeres is regulated by DNA methylation, which enables telomeric-stabilized protein inhibition or expression [41].

Telomerase counteracts telomere shortening to maintain telomeres in the vasculature. Still, telomere attrition occurs with each mitotic cycle due to the fact that telomerase activity (TA) is typically low or absent in human somatic cells $[3,42,43]$. Telomerase contains two main components to compensate this loss by adding DNA sequences to the end of chromosomes. The first component is hTERC, an RNA component, and the second hTERT, a reverse transcriptase. While hTERC expression extends telomerase reactivation, hTERT limits telomerase activity [44-47]. Further, hTERT regulates is transcriptional genes involved in cell proliferation and extension of the lifespan in numerous cell types, such as vSMCs, fibroblasts (FBs) and ECs.

The latest findings of the non-canonical functions of telomerase have shown that hTERT expression influenced cell growth, regardless of telomere maintenance [48]. Moreover, extra-telomeric features of telomerase uncovered an independent role of telomere extension [49]. In detail, the non-canonical functions of the hTERT catalytic subunit are particularly involved in cancer progression with two major signaling mechanisms, which are namely the NF- $\mathrm{kB}$ and Wnt/ $\beta$-catenin pathways. TERT conducts as a transcriptional modulator in tumor cells to sustain its own levels and to control the induction of target genes critical for tumor cell survival and proliferation [49].

A second and rare maintaining mechanism of telomere length found in approximately $10-15 \%$ of tumors is a recombinant process, the alternative lengthening of telomeres (ALT), which results from homologous recombination [50,51]. The ALT mechanism has not been found in human aortic cells and has not been shown to be active in TAA or AAA.

Telomere exhaustion is a major age-dependent problem as aging is known to be a risk factor for vascular diseases [48]. The environmental impact might also be of great importance for telomere shortening during the development of aortic diseases. Thus, for many reasons, TL and telomerase play a critical role in aneurysm formation, as they are associated with adverse lifestyle and cardiovascular diseases (CVD).

\section{Telomeres and Pathobiology of Aortic Aneurysms}

Telomeres have a length genetically determined at birth. TL provides a potential marker for an individual's biological age. There is a lack of knowledge about genetic predispositions in telomere maintenance during aging and its direct relation to the integrity of the aortic tissue. There is little evidence for an association between the genomic determinants of TL and the risk of AAA [52]. Balistreri and his group showed a correlation between age-dependent aneuploidy and TL of the human vascular endothelium [53]. TL was inversely correlated with age and further increased significantly with the frequency of aneuploidy of vascular ECs.

Telomere shorting and the associated genetic instability in vasculature plays a key role in TAA etiology [54]. Recent studies can be divided into two groups: (a) measurements of TL and telomere maintenance mechanisms in diseased aortic tissue, compared to healthy aortic tissue; and (b) comparative studies of white blood cells (WBC) TL with healthy and diseased aortic tissues. In this section, the telomeric specificity of aortic tissue will be summarized.

Artery walls of large vessels consist of layers known as the tunica intima, the tunica media and the tunica adventitia. Their main cell types include ECs, vSMCs, FBs and macrophages [55]. The intimal layer is essentially comprised of ECs. These cells have substantial influence on vSMC differentiation [56] and recent studies have showed that ECs can directly influence the vSMC 
phenotype $[57,58]$. The blood vessel tone is maintained by differentiated vSMCs, which regulate the blood pressure through constriction or relaxation. ECs and vSMCs are key players in vasculogenesis, which is important for structural stability and maintenance during cellular stress or vascular damage to preserve aortic integrity.

Previously, Okuda et al. assumed that a higher rate of telomere attrition enhances the rate of senescence of endothelial cells, which further increases the predilection for vascular disease. Cell senescence has higher significance in their main focus, the distal aorta. They also analyzed the proximal aortic tissue with the following main findings: the TL of intimal tissue was age-dependent, whereas the proximal medial aortic tissue near to the ascending aorta showed no significant age-dependent telomere attrition. Local factors such as shear wall stress may influence such findings being partially representative to vascular cell senescence [59].

The associations between telomerase, aortic aneurysms, epidemiological and clinical variables have been investigated in different studies, although they were limited to AAA. Dimitroulis et al. suggested a protective role of telomerase against AAA formation as studies showed that patients suffering from AAA had attenuated endothelial telomerase expression compared to controls [60]. However, there are almost no studies on this subject, which is why we designed a study to evaluate TL in TAAs, which involves the use of bicuspid (BAV) and tricuspid (TAV) aortic valves in TAAs [61]. We isolated aortic SMCs and subjected them to cell biological and gene expression analyses. The obtained data indicate that aneurysmal SMCs have reduced proliferation and migration rates compared to controls. Moreover, we demonstrated shorter telomeres in aneurysms compared to controls. Further analysis showed a difference between SMCs isolated from TAAs compared to those isolated from BAV and TAV. BAV SMCs had significantly shorter telomeres, whereas TAV SMCs showed reduced metabolic activity. Our study provides evidence that TAA-associated aortic wall disintegration shows similarities in both BAV and TAV, although there are still significant differences.

Several preclinical studies support the idea that age-related endothelial and myocyte dysfunction could contribute to the development of AAA. Bhayadia et al. investigated aortas in telomerase-deficient mice and found significantly higher expressions of stress-induced senescence markers p16(INK4a) and p19(ARF) compared to wild-type mice. This observation eliminated the possibility that loss of telomerase expression or loss of previously reported telomere-independent, non-canonical functions of telomerase $[62,63]$ result in endothelial dysfunction of the aorta. Focusing on ECs, Bianchessi et al. aimed to define whether mitochondrial DNA (mtDNA)-transcribed long-non-coding-RNA plays a role in vascular aging. Senescent cells in aortas of old mice showed increased lncRNA expression. Transient overexpression of lncRNA was shown to induce G2/M cell accumulation and replicative senescence in ECs. In vitro analysis established that these changes are induced in ECs, but not in vSMCs [64]. Boe et al. established plasminogen activator inhibitor-1 (PAI-1) as an important determinant of vascular senescence in vivo, which is one of the major anti-fibrinolytic proteins. It is expressed in ECs and appears to play a pivotal role in vascular aging and hypertension. Telomeres and TL have been examined in aortic tissue from animals treated with PAI-1. The results showed significant induction of senescence and accelerated aging, leading to the conclusion that PAI-1 inhibition maintains TL [65]. Additionally, Thannickal et al. described that the removal of senescent cells can protect the organism against aging [66].

In summary, shortening of telomeres, reduced telomerase function and cellular senescence of vSMCs and ECs seems to play crucial roles in the development of TAAs. Further studies with a greater cohort of samples are necessary to understand the role of genetically-determined aortic TL.

\section{Regulation of Telomeres and Senescence in Cells of the Aortic Wall}

Given the high impact of TL in cells of the aortic wall, it is essential to understand telomere regulation in an age-related manner. Previous in vivo data have suggested that telomerase activation is pivotal for the regulation of vSMC, EC proliferation and long-term cell viability [67]. 
The age-dependent function of EC impairs angiogenesis and the development of vascular diseases [68,69]. In vivo observed EC is remarkably inert until activated to proliferate after traumatic injuries, inflammation and tumor formation [70].

Telomere attrition has been detected in senescent ECs, even though telomerase in these cells inhibits the onset of senescence. Telomere shortening correlates with reduced growth rate of older human ECs [71,72]. Telomerase ectopic overexpression increases the proliferation rate of human ECs and vSMCs $[73,74]$. Studies demonstrate that the reactivation of telomerase in telomerase-negative cells can be induced by hTERT. Contrary studies in mice lacking TA show compromised cell proliferation and reduced tumorigenesis. In detail, phosphorylation of TERT is important to activate telomerase in the nucleus during vSMC proliferation [75]. Yang et al. described a resistance of hTERT-expressing ECs to the induction of apoptosis by different conditions related to parental cells at senescence [76]. Moreover, this group reported an inverse relationship between TA and apoptosis in these cells for the first time. The telomeres were only elongated to a specific length, which allowed the cells to bypass senescence, although they did not reach TL as described for hTERT-immortalized cells.

Another stimulus for TA in ECs is the fibroblast growth factor 2 (FGF-2). FGF-2 expression also delays the onset of senescence in aortic ECs [77]. However, sirtuin-6 (SIRT6) is highly expressed in ECs, fibroblasts, embryonic stem cells and tumor cell lines, where it protects DNA repair and telomere maintenance [78-80]. In this context, the finding that a depletion of SIRT6 in ECs induces a senescent phenotype suggests that increasing the levels or activity of this protein may be a relevant approach for delaying vascular ageing.

Importantly, senescence of vSMCs contributes to aging and age-related diseases of the cardiovascular system. Prolonged cell arrest in mitosis may cause disorder of TRF2 and the telomere structure [81]. Accordingly, Bielak-Zmijewska et al. analyzed the pathways of replicative senescence of vSMCs in vitro. The cellular senescence was induced in doxorubicin (DOX)-treated cardiomyocytes, which led to a stress-induced program of senescence (SIPS) in these cells as previously described [82]. A major role of telomere dysfunction is the stress-induced senescence and apoptosis [83]. Ogawa et al. demonstrated that mitogen-induced TA in VSMCs is inhibited by peroxisome proliferator activated receptor- $\gamma$ (PPAR $\gamma)$ ligands. Furthermore, vSMC treated with PPAR $\gamma$ ligands reduced cell proliferation, which was prevented in cells overexpressing TERT. This finding characterizes TA as an important anti-proliferative target for PPAR $\gamma$ ligands [84].

Hypoxia is a well-known regulator of vascular function and structure, which extends the proliferation capacity of vSMCs through increased TA. Conversely, vSMC growth arrest occurs after telomerase inhibition [85], while senescent vSMCs are accelerated by oxidative stress-induced DNA damage, inhibition of telomerase and marked TL in arteriosclerosis [86]. Similar findings are found in ECs, where oxidative stress induces a downregulation of telomerase and increases telomere damage [87]. Antioxidants prevented TERT downregulation in ECs [88]. In atherosclerotic vessels, telomere shortening is prone to high hemodynamic stresses, which might also enhance EC turnover $[59,71]$.

\section{Factors Affecting Telomeres and the Risk for TAA Formation}

In vitro and in vivo findings have analyzed the link between telomeric integrity and factors influencing TAA formation. First, we discuss unifying pathophysiological mechanisms, which are responsible for ageing and age-related disorders.

\subsection{Oxidative Stress}

Accumulation of oxidative damage plays an important role in age-related telomere dysfunction of vascular cells [89]. Oxidative stress is defined as an increase in the intra-cellular concentration of reactive oxygen species (ROS) $[90,91]$. ROS are generated during the regular mitochondrial electron transport chain. Other ROS species can be derived from superoxide and hydrogen peroxide, which are associated with the depletion of extracellular matrix proteins. ROS is proposed to be involved in TAA 
development. In aortic tissue, increased ROS levels were detected in aneurysmal aortas compared to non-aneurysmal aortas of patients and were confirmed to play an important factor in the development of aneurysms [92]. Knockout mice with suppressed ROS production had reduced TAA formation [93]. Moreover, ROS induces genomic instability and loss of DNA stabilization factors, which was shown in thoracic aneurysmal vSMCs [94].

Telomerase is not only located within the nucleus and cytoplasm, but also be found in the mitochondria [95]. The telomerase located in the nucleus plays a crucial role in telomere elongation, gene expression regulation, chromatin organization and DNA-damage responses [96]. In contrast, the telomerase found in mitochondria is involved in regulation and influences apoptosis, stress protection, transfer-RNA-dependent reverse transcriptase and RNA-dependent RNA polymerase. However, in context with ROS and oxidative stress, mitochondrial telomerase reduces the production of ROS and protects mitochondrial DNA from damage [62,63]. Interestingly, telomerase seems to have an anti-apoptotic role, with the potential to block mitochondrial [14] and death receptor pathways [97].

Telomere shortening has been associated with oxidative stress by finding oxygen radicals in EC, vSMC, epidermal cells and WBCs from AAA patients [98]. Most recently, Rehh et al. demonstrated that triplet guanines present in telomeric TTAGGG-repeats is linked to the preferential accumulation of oxidative stress-related damage in telomeres [99]. An inverse correlation was detected between TL and high levels of oxidative DNA damage in WBCs from AAA patients. This suggests that oxidative stress has systematic effects, similar to telomere shortening [97]. The relationship between telomere shortening and oxidative stress is still under discussion.

The studies are suggesting the idea that oxidative stress inhibits TA and causes telomere attrition. Moreover, the non-canonical mitochondrial specific role of TERT is focused on protection against oxidative stress. Therefore, a regulation of TERT will be a promising target in the development of therapeutic treatments, which affecting telomerase, in aging and telomere related diseases.

Beyer et al. identified that increasing TA reverses the pathological phenotype seen in CVD [100]. This study supports the hypothesis that TA in mitochondria regulates ROS production with direct physiological impact. Moreover, new findings in CVD showed that nicotinamide adenine dinucleotide phosphate (NADPH) oxidase plays an essential role in the development of diseases. For example, $\mathrm{Xu}$ et al. have demonstrated that NADPH oxidase increases the proportion of SMC phenotypes associated with atherosclerotic plaques vulnerability [101]. There is a lack of data related to these findings in TAAs, although this should be a promising field of disease research.

\subsection{Nutrition}

It is well known that an increase of caloric intake and, consequently, obesity are known to reduce the average age. Specially, the adipose tissue plays a crucial role, which influences the function and structural integrity of the cardiovascular system as a source of ROS [102]. Unhealthy diet, high glucose (e.g., fructose) and low-density lipoprotein intake [103] are associated with an increased risk of CVD. As human primary cardiovascular cells show phenotypic and molecular changes. Simulated unhealthy diets showed enhanced proliferation of SMCs and increased senescence as well as loss of endothelial nitric oxide synthase (eNOS) in ECs in vitro. Further, the protein restriction during lactation for maternal animals showed a reduction of DNA damage and shortens telomeres in aortic tissue. These results are associated with reduced 8-hydroxy-2-deoxyguanosine, a marker of oxidative stress, which has a positive effect on child growth and cardiovascular diseases [104].

\subsection{Hypertension}

Hypertension is a significant contributor to telomere attrition [105]. The potential relationship between TL and human hypertension were examined in several studies. Two large studies, the Framingham heart study and the cardiovascular health study, have suggested that hemodynamic stress in linked to telomere shortening [24,106]. In the Framingham Heart Study, leukocytes TL of hypertensive male subjects are significant shorter compared with their normotensive peers. 
The molecular basis of the abnormality in hypertension has not been fully defined as vascular remodeling in arterial vessels with high blood pressure. Studies in telomerase-deficient mice have shown a direct association between hypertension and telomere attrition [107]. Cao et al. designed an animal study with spontaneously hypertensive rats and analyzed aortic tissue [67]. Telomerase was selectively activated, while telomeres were lengthened in vivo and in vitro. Moreover, telomerase was found to play a significant role in aortic tissue. Thus, the downregulation of hTERT arrests the increased proliferation of vSMCs in hypertensive rats. In addition, the study showed that the p53 checkpoint appears to be crucial for increased vSMC growth rate. The molecular targeting of this increased activity may thus provide a window of opportunity for preventing high blood pressure. In contrast, the study from Dimitroulis showed that differences in telomerase RNA expression between AAAs and controls were independent of other factors, such as age and hypertension [60]. Summarizing, a reduction of TL is associated with increased EC growth rate that seems to be a consequence of vascular shear stress.

\subsection{Diabetes Mellitus}

Diabetic patients are at higher risk of vascular diseases [108] as post-prandial hyperglycemia increases cardiovascular risk. Diabetes and hyperhomocysteinemia have been shown to be independent risk factors for increased progression of CVD, including TAA and AAA [109]. vSMC cultures exposed to high levels of glucose or/and homocyteine (Hcy) showed increased TA, which resulted in a proliferative response of vSMCs [109]. In contrast, Matsui et al. showed that high plasma concentrations of insulin therapy might accelerate endothelial senescence [110]. Human ECs exposed to high glucose increased senescence markers and decreased TA. Preserved TL and delayed senescence in ECs under high-glucose conditions were preserved with normal concentrations of insulin. Moreover, these effects were associated with reduced reactive oxygen species and increased nitric oxide (NO). These results may help to explain the complicated roles of insulin in CVD in the elderly [110]. Nevertheless, recent studies have claimed that diabetes has a protective role regarding the formation of abdominal aortic aneurysms. Further studies need to elucidate whether this protection is based on the effect of different anti-diabetic medications (which are known to potentially reduce oxidative stress within the vascular wall).

\section{Telomeres as Markers in Leukocytes}

In the early 1990s [111], it was speculated that TL measured in leukocytes is a marker for increasing age. Biological age seems to be a more descriptive predictor of CVD rather than chronological age [112]. Non-functional vascular ECs provoke a transendothelial migration and adhesion of circulating leukocytes. These circulating blood leukocytes reflect the biological age of vascular walls and are associated with a reduction of TL and CVD [113,114].

Patients with AAA showed shorter leukocyte TL compared to controls [115]. The measurement of leukocyte DNA mirroring for vascular telomere content seems to be an accurate surrogate for human vascular age [114]. Additional factors (e.g., genetic and environmental) are involved in telomere shortening, suggested by an inverse correlation between TL and oxidative DNA damage in a wide spectrum of inflammatory and degenerative disorders [98]. The pathological progression of atherosclerosis in AAA is induced by an inflammatory process, which is mainly responsible for a high cellular turnover and therefore, rapid telomere shortening [116].

The risk factors for telomere attrition and a decrease of TA in TAA patients are significantly associated with an increased systemic inflammation, age, gender, nicotine abuse and high blood pressure $[117,118]$. An inverse correlation between short TL and chronic vascular diseases in a high-risk population of chronic kidney disease (CKD) patients was found [119]. Whereby, the most significant associations were found for carotid arteries interventions, TAA and AAA.

Interestingly, the group of Salonurmi analyzed TL in TAAs and demonstrated opposite results [113]. Salonurmi et al. detected TL by using the Cawthon's quantitative (q) PCR methods, while other groups measured TL by comparing the mean terminal restriction fragments (TRF) length by using the more precise Southern Blot analysis. In all studies, several limitations need to be considered. 
TL varies between different chromosomes and cell types. Measurement of the mean TRF length is inexact to analyze cellular telomere attrition. As critical telomere shortening of a single chromosome does not affecting the mean TRF length. Therefore, one point of interest should be the signals from telomeric DNA damage in aortic tissue and WBCs of same patients.

Yan et al. has demonstrated significantly shorter leukocyte TL in a Chinese population affected by aortic dissections compared to a control group without vascular diseases [20]. After adjustments for other risk factors the short leukocyte TL was associated with aortic dissection.

Several factors have contributed to the lag of telomere measurements in patients and data interpretation. This includes technical obstacles for large-scale measurements and lack of standardization across techniques and laboratories, apart from the strong association with risk factors in patients. In clinical practice, age, gender and lifestyle also play an important role, which makes the usage of TL measurement as a biomarker difficult and controversial discussed.

\section{Mechanism to Preserve Telomere Length}

A comprehensive health concept, including maintenance of high-intensity physical exercise and a well-balanced diet, has been suggested for preserving TL by activating telomerase even in old age [120,121]. The cardiovascular benefits of chronic exercise are found in WBCs isolated from endurance athletes. Compared to untrained individuals, endurance athletes have increased TA, higher levels of expression of telomere-stabilizing proteins and significant lower levels of cellular growth arrest and cell death markers. Although all parameters, such as heart rate, blood pressure, body mass index and lipid profile, are beneficial in athletes, the positive TBP regulation was independent.

In the context of a healthy diet, several nutritional components have been shown to have a positive correlation with increased TA [122]. Balanced intake of marine omega-3 fatty acid lowers the rate of telomere shortening [123]. Resveratrol found in grapes, blueberry, raspberry and mulberry activates human nicotinamide phosphoribosyltransferase, sirtuin- 4 and the reverse transcriptase of telomerase in human aortic SMCs. This also decreased the expression of $\mathrm{p} 53$ by $50 \%$ and increased $\mathrm{TL}$, which delayed vascular aging [124]. A dietary supplement, Shoushen Granule, was shown to improve atherosclerotic lesions of the arterial wall by decreasing total cholesterol and low-density lipid cholesterol levels and increasing TA and TL in peripheral leukocytes and vascular cells [125]. Furthermore, rice bran, a by-product of the rice milling process, contains $\gamma$-oryzanol, tocopherols and phytosterols. Positively effects can be attributed to rice bran, as lipid-lowering and anti-inflammatory effects. The enzymatic extract of rice bran prevents telomere shortening in aorta and mononuclear cells and reduces vascular apoptosis and atherogenesis in mice. Presently, the exact mechanism by which resveratrol, Shoushen Granule or rice bran induces telomerase remains unknown; these findings suggest a beneficial effect in anti-aging processes in diseased cardiovascular cells.

TL can also be preserved by pharmaceuticals. Aspirin, angiotensin-converting-enzyme (ACE) inhibitors and statin therapy have been shown to have an anti-senescence effect on the vascular endothelium [126-130]. Pioglitazone, a drug of the thiazolidinedione class, increase TA in aortic cells and prevents stress-induced cell death of ECs. It reduces levels of senescence markers p16, cell-cycle checkpoint kinase 2 and p53 [84,131]. Activation of liver X receptors (LXRs), which are nuclear receptors, are triggers for protection of arteries against atherosclerosis. LXR ligands stabilize low levels of senescence-associated $\beta$-gal activity, and reverse the decrease of telomerase expression in human ECs. This effect of LXR activation was associated with reduced ROS and increased eNOS activity [132].

\section{Conclusions}

Genetic dispositions, such as the Ehlers-Danlos Syndrome or Marfan Syndrome, and vascular risk factors (e.g., smoking and obesity) appear to be strong risk factors for AAA. Studies in animal and human trials associate a reduced TL and an inherent TA with DNA damage and increased predisposition to form AAAs. In summary, following findings show the link between telomere biology and TAA (Figure 1). (1) Shortened telomeres reduced telomerase function. Therefore, premature 
senescence of vSMCs and ECs are strongly associated with the development of aortic aneurysms; (2) Aneurysm formation results from abnormal proliferation and/or degeneration of vSMCs and ECs in the aortic wall, whereas the induction of TA is essential for the regulation of vSMC and ECs proliferation, which occurs independently of progressive telomere shortening; (3) Shortened telomeres in aneurysmal aortic tissue were correlated with telomere attrition in white blood cells.

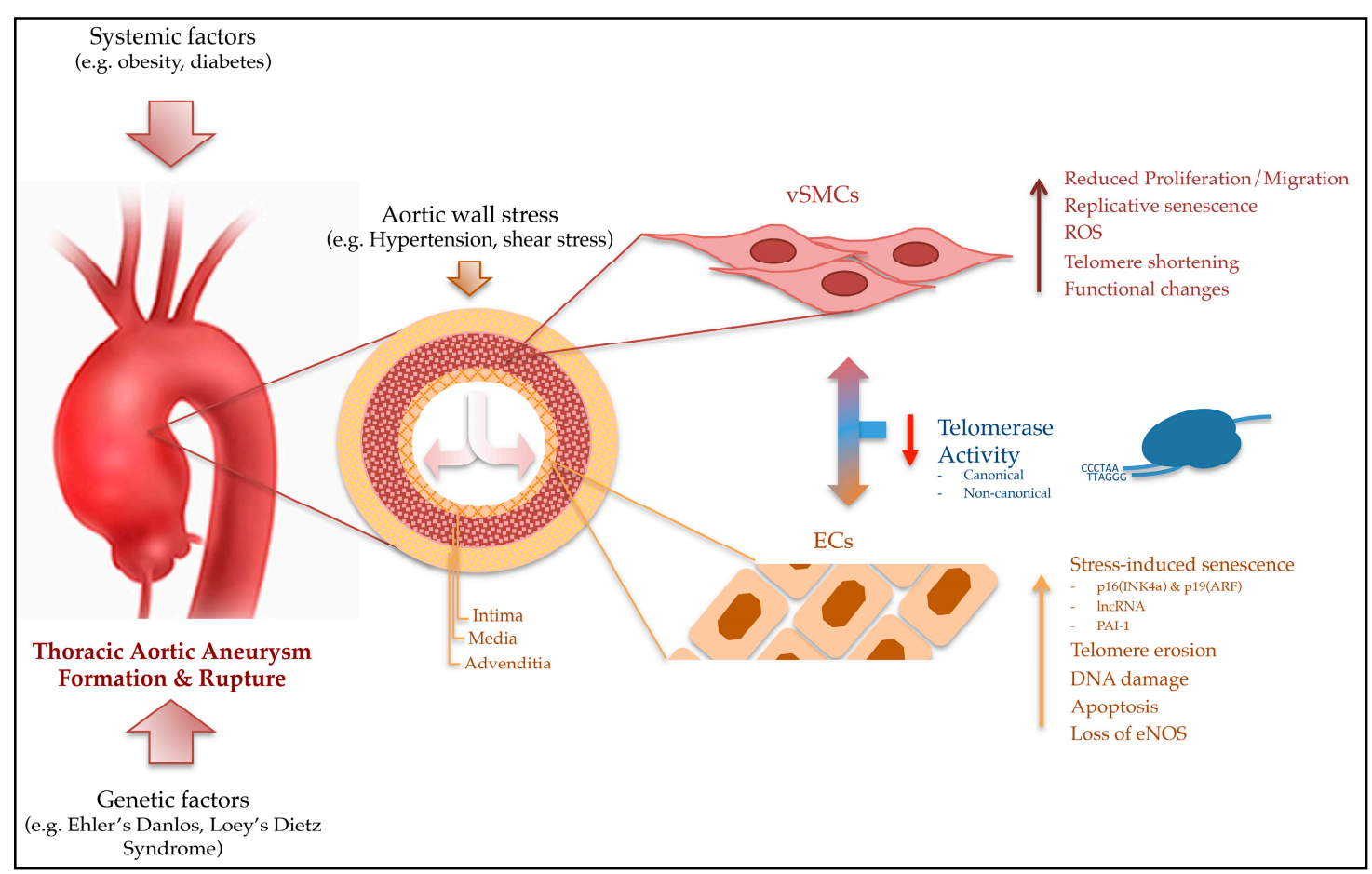

Figure 1. Multiple factors are associated with thoracic aortic aneurysm formation. The influence of telomerase activity on vascular smooth muscle cells (vSMC) and endothelial cells (EC) and the regulatory interaction between both cells is of particular importance.

A considerable number of reports suggest that telomerase and its key components, TERT and TERC, have functions beyond their ability to lengthen telomeres. TA is found in a wide range of cell types and tissue to be involved in a variety of activities, especially with non-canonical functions that have not been fully characterized. In aortic cells, telomerase seems to works as a transcription co-factor that regulates the expression of genes involved in the regulation of cell proliferation, differentiation and apoptosis.

TL seems to be an attractive new biomarker for biological age or for follow-up of aneurysm progression over years. However, TL needs to be interpreted with caution due to the formation and the progression of TAA over decades. Little is known about telomere attrition in the earlier stages of disease. Interestingly, telomere shortening is accelerated prior to the onset of clinical disease. A variety of risk factors, such as age, gender, smoking and obesity, have a great influence on both TL and the health of most patients. Therefore, the non-specific modulations of TL suggest a poor specificity and limited potential as a biomarker of a specific disease.

Hence, the main questions related to telomere regulation and the development of aortic aneurysms remain unanswered: Does telomere-shortening lead to the development of TAA or does the DNA damage caused by external factors (e.g., hypertonic blood flow) reduce TL in aortic cells? Prospective longitudinal studies would be required for accurate delineation of true changes in TL.

Conflicts of Interest: The authors declare no conflicts of interest.

Funding: Supported in part by grants from the Medical-Scientific Fund of the Mayor of Vienna (Project-No. 15155). 


\section{Abbreviations}

$\begin{array}{ll}\text { AAA } & \text { Abdominal aortic aneurysm } \\ \text { ALT } & \text { Alternative lengthening of telomeres } \\ \text { BAV } & \text { Bicuspid aortic valve } \\ \text { CKD } & \text { Chronic kidney disease } \\ \text { CVD } & \text { Cardiovascular disease } \\ \text { DOX } & \text { Doxorubicin } \\ \text { ds/ss } & \text { Double-stranded/single-stranded } \\ \text { DSB } & \text { Double strand break } \\ \text { EC } & \text { Endothelial cell } \\ \text { eNOS } & \text { Endothelial nitrate oxide synthase } \\ \text { FB } & \text { Fibroblast } \\ \text { LXR } & \text { Liver X receptor } \\ \text { NAMPT } & \text { Nicotinamide phosphoribosyltransferase } \\ \text { NO } & \text { Nitride oxide } \\ \text { PAI-1 } & \text { Plasminogen activator inhibitor-1 } \\ \text { PARP } & \text { poly-ADP ribose polymerase } \\ \text { POT1 } & \text { Protection of telomeres 1 } \\ \text { RAP1 } & \text { Repressor activator protein-1 } \\ \text { ROS } & \text { Reactive oxygen species } \\ \text { RTL } & \text { Relative telomere length } \\ \text { SIPS } & \text { Stress-induced senescence program } \\ \text { (v)SMC } & \text { (vascular)smooth muscle cell } \\ \text { TA } & \text { Telomerase activity } \\ \text { TAA } & \text { Thoracic aortic aneurysm } \\ \text { TAV } & \text { Tricuspid aortic valve } \\ \text { TBP } & \text { Telomere binding protein } \\ \text { (h)TERC/(h)TR } & \text { (human)telomerase RNA-component } \\ \text { (h)TERT } & \text { (human)telomerase reverse transcriptase } \\ \text { TIN2 } & \text { TRF1-interacting protein 2 } \\ \text { TL } & \text { Telomere length } \\ \text { TPP1 } & \text { Tripeptidyl peptidase 1 } \\ \text { TRF } & \text { TZlomere repeat-binding factor } \\ \text { WBC } & \text { Thinger-associated protein } \\ & \end{array}$

\section{References}

1. Moyzis, R.K.; Buckingham, J.M.; Cram, L.S.; Dani, M.; Deaven, L.L.; Jones, M.D.; Meyne, J.; Ratliff, R.L.; $\mathrm{Wu}$, J.R. A highly conserved repetitive DNA sequence, (TTAGGG)n, present at the telomeres of human chromosomes. Proc. Natl. Acad. Sci. USA 1988, 85, 6622-6626. [CrossRef] [PubMed]

2. Blackburn, E.H. Telomeres. Trends Biochem. Sci. 1991, 16, 378-381. [CrossRef]

3. Kim, N.W.; Piatyszek, M.A.; Prowse, K.R.; Harley, C.B.; West, M.D.; Ho, P.L.; Coviello, G.M.; Wright, W.E.; Weinrich, S.L.; Shay, J.W. Specific association of human telomerase activity with immortal cells and cancer. Science 1994, 266, 2011-2015. [CrossRef] [PubMed]

4. Harley, C.B.; Futcher, A.B.; Greider, C.W. Telomeres shorten during ageing of human fibroblasts. Nature 1990, 345, 458-460. [CrossRef] [PubMed]

5. Counter, C.M.; Avilion, A.A.; LeFeuvre, C.E.; Stewart, N.G.; Greider, C.W.; Harley, C.B.; Bacchetti, S. Telomere shortening associated with chromosome instability is arrested in immortal cells which express telomerase activity. EMBO J. 1992, 11, 1921-1929. [PubMed]

6. Karlseder, J.; Smogorzewska, A.; de Lange, T. Senescence induced by altered telomere state, not telomere loss. Science 2002, 295, 2446-2449. [CrossRef] [PubMed] 
7. Martínez, P.; Blasco, M.A. Telomeric and extra-telomeric roles for telomerase and the telomere-binding proteins. Nat. Rev. Cancer 2011, 11, 161-176. [CrossRef] [PubMed]

8. De Lange, T. Protection of mammalian telomeres. Oncogene 2002, 21, 532-540. [CrossRef] [PubMed]

9. De Lange, T. Shelterin: The protein complex that shapes and safeguards human telomeres. Genes Dev. 2005, 19, 2100-2110. [CrossRef] [PubMed]

10. Blasco, M.A. Telomeres and human disease: Ageing, cancer and beyond. Nat. Rev. Genet. 2005, 6, 611-622. [CrossRef] [PubMed]

11. Morin, G.B. The human telomere terminal transferase enzyme is a ribonucleoprotein that synthesizes TTAGGG repeats. Cell 1989, 59, 521-529. [CrossRef]

12. Fleisig, H.B.; Hukezalie, K.R.; Thompson, C.A.; Au-Yeung, T.T.; Ludlow, A.T.; Zhao, C.R.; Wong, J.M. Telomerase reverse transcriptase expression protects transformed human cells against DNA-damaging agents, and increases tolerance to chromosomal instability. Oncogene 2016, 35, 218-227. [CrossRef] [PubMed]

13. Kinoshita, T.; Nagamatsu, G.; Saito, S.; Takubo, K.; Horimoto, K.; Suda, T. Telomerase reverse transcriptase has an extratelomeric function in somatic cell reprogramming. J. Biol. Chem. 2014, 289, 15776-15787. [CrossRef] [PubMed]

14. Xi, L.; Chen, G.; Zhou, J.; Xu, G.; Wang, S.; Wu, P.; Zhu, T.; Zhang, A.; Yang, W.; Xu, Q.; Lu, Y.; Ma, D. Inhibition of telomerase enhances apoptosis induced by sodium butyrate via mitochondrial pathway. Apoptosis 2006, 11, 789-798. [CrossRef] [PubMed]

15. Forsdahl, S.H.; Singh, K.; Solberg, S.; Jacobsen, B.K. Risk factors for abdominal aortic aneurysms: A 7-year prospective study: The Tromso Study, 1994-2001. Circulation 2009, 119, 2202-2208. [CrossRef] [PubMed]

16. El-Hamamsy, I.; Yacoub, M.H. Cellular and molecular mechanisms of thoracic aortic aneurysms. Nat. Rev. Cardiol. 2009, 6, 771-786. [CrossRef] [PubMed]

17. Booher, A.M.; Eagle, K.A.; Bossone, E. Acute aortic syndromes. Herz 2011, 36, 480-487. [CrossRef] [PubMed]

18. Morgan, R.G.; Ives, S.J.; Lesniewski, L.A.; Cawthon, R.M.; Andtbacka, R.H.; Noyes, R.D.; Richardson, R.S.; Donato, A.J. Age-related telomere uncapping is associated with cellular senescence and inflammation independent of telomere shortening in human arteries. Am. J. Physiol. Heart Circ. Physiol. 2013, 305, H251-H258. [CrossRef] [PubMed]

19. De Meyer, T.; Rietzschel, E.R.; De Buyzere, M.L.; Van Criekinge, W.; Bekaert, S. Telomere length and cardiovascular aging: The means to the ends? Ageing Res. Rev. 2011, 10, 297-303. [CrossRef] [PubMed]

20. Yan, J.; Yang, Y.; Chen, C.; Peng, J.; Ding, H.; Wang, D.W. Short leukocyte telomere length is associated with aortic dissection. Intern. Med. 2011, 50, 2871-2875. [CrossRef] [PubMed]

21. Epel, E.S.; Merkin, S.S.; Cawthon, R.; Blackburn, E.H.; Adler, N.E.; Pletcher, M.J.; Seeman, T.E. The rate of leukocyte telomere shortening predicts mortality from cardiovascular disease in elderly men. Aging 2008, 1, 81-88. [CrossRef] [PubMed]

22. Mainous, A.G.; Diaz, V.A. Telomere length as a risk marker for cardiovascular disease: The next big thing? Expert Rev. Mol. Diagn. 2010, 10, 969-971. [CrossRef] [PubMed]

23. Huzen, J.; de Boer, R.A.; van Veldhuisen, D.J.; van Gilst, W.H.; van der Harst, P. The emerging role of telomere biology in cardiovascular disease. Front. Biosci. 2010, 15, 35-45. [CrossRef]

24. Fitzpatrick, A.L.; Kronmal, R.A.; Kimura, M.; Gardner, J.P.; Psaty, B.M.; Jenny, N.S.; Tracy, R.P.; Hardikar, S.; Aviv, A. Leukocyte telomere length and mortality in the Cardiovascular Health Study. J. Gerontol. A Biol. Sci. Med. Sci. 2011, 66, 421-429. [CrossRef] [PubMed]

25. Ince, H.; Nienaber, C.A. Etiology, pathogenesis and management of thoracic aortic aneurysm. Nat. Clin. Pract. Cardiovasc. Med. 2007, 4, 418-427. [CrossRef] [PubMed]

26. Elefteriades, J.A.; Farkas, E.A. Thoracic aortic aneurysm clinically pertinent controversies and uncertainties. J. Am. Coll. Cardiol. 2010, 55, 841-857. [CrossRef] [PubMed]

27. Aviv, A.; Levy, D. Telomeres, atherosclerosis, and the hemothelium: The longer view. Annu. Rev. Med. 2012, 63, 293-301. [CrossRef] [PubMed]

28. Aviv, A. Genetics of leukocyte telomere length and its role in atherosclerosis. Mutat. Res. 2012, 730, 68-74. [CrossRef] [PubMed]

29. Watson, J.D. Origin of concatemeric T7 DNA. Nat. New Biol. 1972, 239, 197-201. [CrossRef] [PubMed]

30. Olovnikov, A.M. A theory of marginotomy. The incomplete copying of template margin in enzymic synthesis of polynucleotides and biological significance of the phenomenon. J. Theor. Biol. 1973, 41, 181-190. [CrossRef]

31. Blackburn, E.H. Structure and function of telomeres. Nature 1991, 350, 569-573. [CrossRef] [PubMed] 
32. Samassekou, O.; Gadji, M.; Drouin, R.; Yan, J. Sizing the ends: Normal length of human telomeres. Ann. Anat. 2010, 192, 284-291. [CrossRef] [PubMed]

33. Palm, W.; de Lange, T. How shelterin protects mammalian telomeres. Annu. Rev. Genet. 2008, 42, 301-334. [CrossRef] [PubMed]

34. Choi, K.H.; Farrell, A.S.; Lakamp, A.S.; Ouellette, M.M. Characterization of the DNA binding specificity of Shelterin complexes. Nucleic Acids Res. 2011, 39, 9206-9223. [CrossRef] [PubMed]

35. Li, J.S.; Fuste, J.M.; Simavorian, T.; Bartocci, C.; Tsai, J.; Karlseder, J.; Denchi, E.L. TZAP: A telomere-associated protein involved in telomere length control. Science 2017, 355, 638-641. [CrossRef] [PubMed]

36. Nera, B.; Huang, H.S.; Lai, T.; Xu, L. Elevated levels of TRF2 induce telomeric ultrafine anaphase bridges and rapid telomere deletions. Nat. Commun. 2015, 6, 10132. [CrossRef] [PubMed]

37. Tomimatsu, N.; Tahimic, C.G.; Otsuki, A.; Burma, S.; Fukuhara, A.; Sato, K.; Shiota, G.; Oshimura, M.; Chen, D.J.; Kurimasa, A. Ku70/80 modulates ATM and ATR signaling pathways in response to DNA double strand breaks. J. Biol. Chem. 2007, 282, 10138-10145. [CrossRef] [PubMed]

38. Oeseburg, H.; de Boer, R.A.; van Gilst, W.H.; van der Harst, P. Telomere biology in healthy aging and disease. Pflïgers Arch. Eur. J. Physiol. 2010, 459, 259-268. [CrossRef] [PubMed]

39. Schreiber, V.; Dantzer, F.; Ame, J.C.; de Murcia, G. Poly(ADP-ribose): Novel functions for an old molecule. Nat. Rev. Mol. Cell Biol. 2006, 7, 517-528. [CrossRef] [PubMed]

40. Dantzer, F.; Ame, J.C.; Schreiber, V.; Nakamura, J.; Menissier-de Murcia, J.; de Murcia, G. Poly(ADP-ribose) polymerase-1 activation during DNA damage and repair. Methods Enzymol. 2006, 409, 493-510. [PubMed]

41. Saliques, S.; Zeller, M.; Lorin, J.; Lorgis, L.; Teyssier, J.R.; Cottin, Y.; Rochette, L.; Vergely, C. Telomere length and cardiovascular disease. Arch. Cardiovasc. Dis. 2010, 103, 454-459. [CrossRef] [PubMed]

42. Counter, C.M.; Botelho, F.M.; Wang, P.; Harley, C.B.; Bacchetti, S. Stabilization of short telomeres and telomerase activity accompany immortalization of Epstein-Barr virus-transformed human B lymphocytes. J. Virol. 1994, 68, 3410-3414. [PubMed]

43. Prowse, K.R.; Greider, C.W. Developmental and tissue-specific regulation of mouse telomerase and telomere length. Proc. Natl. Acad. Sci. USA 1995, 92, 4818-4822. [CrossRef] [PubMed]

44. Wright, W.E.; Shay, J.W. Telomere biology in aging and cancer. J. Am. Geriatr. Soc. 2005, 53, S292-S294. [CrossRef] [PubMed]

45. Shay, J.W. Meeting report: The role of telomeres and telomerase in cancer. Cancer Res. 2005, 65, 3513-3517. [CrossRef] [PubMed]

46. Blasco, M.A. Mammalian telomeres and telomerase: Why they matter for cancer and aging. Eur. J. Cell Biol. 2003, 82, 441-446. [CrossRef] [PubMed]

47. Gilson, E.; Segal-Bendirdjian, E. The telomere story or the triumph of an open-minded research. Biochimie 2010, 92, 321-326. [CrossRef] [PubMed]

48. Geserick, C.; Blasco, M.A. Novel roles for telomerase in aging. Mech. Ageing Dev. 2006, 127, 579-583. [CrossRef] [PubMed]

49. Li, Y.; Tergaonkar, V. Noncanonical functions of telomerase: Implications in telomerase-targeted cancer therapies. Cancer Res. 2014, 74, 1639-1644. [CrossRef] [PubMed]

50. Henson, J.D.; Neumann, A.A.; Yeager, T.R.; Reddel, R.R. Alternative lengthening of telomeres in mammalian cells. Oncogene 2002, 21, 598-610. [CrossRef] [PubMed]

51. Lee, S.S.; Bohrson, C.; Pike, A.M.; Wheelan, S.J.; Greider, C.W. ATM Kinase Is Required for Telomere Elongation in Mouse and Human Cells. Cell Rep. 2015, 13, 1623-1632. [CrossRef] [PubMed]

52. Haycock, P.C.; Burgess, S.; Nounu, A.; Zheng, J.; Okoli, G.N.; Bowden, J.; Wade, K.H.; Timpson, N.J.; Evans, D.M.; Willeit, P.; et al. Association Between Telomere Length and Risk of Cancer and Non-Neoplastic Diseases: A Mendelian Randomization Study. JAMA Oncol. 2017, 3, 636-651. [CrossRef] [PubMed]

53. Balistreri, C.R.; Colonna-Romano, G.; Lio, D.; Candore, G.; Caruso, C. TLR4 polymorphisms and ageing: Implications for the pathophysiology of age-related diseases. J. Clin. Immunol. 2009, 29, 406-415. [CrossRef] [PubMed]

54. Khan, S.; Chuturgoon, A.A.; Naidoo, D.P. Telomeres and atherosclerosis. Cardiovasc. J. Afr. 2012, 23, 563-571. [CrossRef] [PubMed]

55. Ross, M.H.; Pawlina, W. Cardiovascular system. In Histology: A Text and Atlas, 5th ed.; Taylor, C., Scogna, K.H., Ajello, J.P., Eds.; Lippincott Williams and Wilkins: Baltimore, MA, USA, 2006; pp. 364-394.

56. Darland, D.C.; D'Amore, P.A. Cell-cell interactions in vascular development. Curr. Top. Dev. Biol. 2001, 52, 107-149. [PubMed] 
57. Lin, C.H.; Lilly, B. Notch signaling governs phenotypic modulation of smooth muscle cells. Vasc. Pharmacol. 2014, 63, 88-96. [CrossRef] [PubMed]

58. High, F.A.; Lu, M.M.; Pear, W.S.; Loomes, K.M.; Kaestner, K.H.; Epstein, J.A. Endothelial expression of the Notch ligand Jagged1 is required for vascular smooth muscle development. Proc. Natl. Acad. Sci. USA 2008, 105, 1955-1959. [CrossRef] [PubMed]

59. Okuda, K.; Khan, M.Y.; Skurnick, J.; Kimura, M.; Aviv, H.; Aviv, A. Telomere attrition of the human abdominal aorta: Relationships with age and atherosclerosis. Atherosclerosis 2000, 152, 391-398. [CrossRef]

60. Dimitroulis, D.; Katsargyris, A.; Klonaris, C.; Avgerinos, E.D.; Fragou-Plemenou, M.; Kouraklis, G.; Liapis, C.D. Telomerase expression on aortic wall endothelial cells is attenuated in abdominal aortic aneurysms compared to healthy nonaneurysmal aortas. J. Vasc. Surg. 2011, 54, 1778-1783. [CrossRef] [PubMed]

61. Blunder, S.; Messner, B.; Aschacher, T.; Zeller, I.; Turkcan, A.; Wiedemann, D.; Andreas, M.; Bluschke, G.; Laufer, G.; Schachner, T.; et al. Characteristics of TAV- and BAV-associated thoracic aortic aneurysms - Smooth muscle cell biology, expression profiling, and histological analyses. Atherosclerosis 2012, 220, 355-361. [CrossRef] [PubMed]

62. Ahmed, S.; Passos, J.F.; Birket, M.J.; Beckmann, T.; Brings, S.; Peters, H.; Birch-Machin, M.A.; von Zglinicki, T.; Saretzki, G. Telomerase does not counteract telomere shortening but protects mitochondrial function under oxidative stress. J. Cell Sci. 2008, 121, 1046-1053. [CrossRef] [PubMed]

63. Haendeler, J.; Drose, S.; Buchner, N.; Jakob, S.; Altschmied, J.; Goy, C.; Spyridopoulos, I.; Zeiher, A.M.; Brandt, U.; Dimmeler, S. Mitochondrial telomerase reverse transcriptase binds to and protects mitochondrial DNA and function from damage. Arterioscler. Thromb. Vasc. Biol. 2009, 29, 929-935. [CrossRef] [PubMed]

64. Bianchessi, V.; Badi, I.; Bertolotti, M.; Nigro, P.; D’Alessandra, Y.; Capogrossi, M.C.; Zanobini, M.; Pompilio, G.; Raucci, A.; Lauri, A. The mitochondrial lncRNA ASncmtRNA-2 is induced in aging and replicative senescence in Endothelial Cells. J. Mol. Cell. Cardiol. 2015, 81, 62-70. [CrossRef] [PubMed]

65. Boe, A.E.; Eren, M.; Murphy, S.B.; Kamide, C.E.; Ichimura, A.; Terry, D.; McAnally, D.; Smith, L.H.; Miyata, T.; Vaughan, D.E. Plasminogen activator inhibitor-1 antagonist TM5441 attenuates Nomega-nitro-L-arginine methyl ester-induced hypertension and vascular senescence. Circulation 2013, 128, 2318-2324. [CrossRef] [PubMed]

66. Thannickal, V.J. Mechanistic links between aging and lung fibrosis. Biogerontology 2013, 14, 609-615. [CrossRef] [PubMed]

67. Cao, Y.; Li, H.; Mu, F.T.; Ebisui, O.; Funder, J.W.; Liu, J.P. Telomerase activation causes vascular smooth muscle cell proliferation in genetic hypertension. FASEB J. 2002, 16, 96-98. [CrossRef] [PubMed]

68. Pili, R.; Guo, Y.; Chang, J.; Nakanishi, H.; Martin, G.R.; Passaniti, A. Altered angiogenesis underlying age-dependent changes in tumor growth. J. Natl. Cancer Inst. 1994, 86, 1303-1314. [CrossRef] [PubMed]

69. Rivard, A.; Fabre, J.E.; Silver, M.; Chen, D.; Murohara, T.; Kearney, M.; Magner, M.; Asahara, T.; Isner, J.M. Age-dependent impairment of angiogenesis. Circulation 1999, 99, 111-120. [CrossRef] [PubMed]

70. Klagsbrun, M.; D'Amore, P.A. Regulators of angiogenesis. Annu. Rev. Physiol. 1991, 53, 217-239. [CrossRef] [PubMed]

71. Chang, E.; Harley, C.B. Telomere length and replicative aging in human vascular tissues. Proc. Natl. Acad. Sci. USA 1995, 92, 11190-11194. [CrossRef] [PubMed]

72. Hastings, R.; Qureshi, M.; Verma, R.; Lacy, P.S.; Williams, B. Telomere attrition and accumulation of senescent cells in cultured human endothelial cells. Cell Prolif. 2004, 37, 317-324. [CrossRef] [PubMed]

73. Minamino, T.; Miyauchi, H.; Yoshida, T.; Tateno, K.; Kunieda, T.; Komuro, I. Vascular cell senescence and vascular aging. J. Mol. Cell. Cardiol. 2004, 36, 175-183. [CrossRef] [PubMed]

74. Poh, M.; Boyer, M.; Solan, A.; Dahl, S.L.; Pedrotty, D.; Banik, S.S.; McKee, J.A.; Klinger, R.Y.; Counter, C.M.; Niklason, L.E. Blood vessels engineered from human cells. Lancet 2005, 365, 2122-2124. [CrossRef]

75. Minamino, T.; Kourembanas, S. Mechanisms of telomerase induction during vascular smooth muscle cell proliferation. Circ. Res. 2001, 89, 237-243. [CrossRef] [PubMed]

76. Yang, J.; Chang, E.; Cherry, A.M.; Bangs, C.D.; Oei, Y.; Bodnar, A.; Bronstein, A.; Chiu, C.P.; Herron, G.S. Human endothelial cell life extension by telomerase expression. J. Biol. Chem. 1999, 274, 26141-26148. [CrossRef] [PubMed]

77. Trivier, E.; Kurz, D.J.; Hong, Y.; Huang, H.L.; Erusalimsky, J.D. Differential regulation of telomerase in endothelial cells by fibroblast growth factor-2 and vascular endothelial growth factor-a: Association with replicative life span. Ann. N. Y. Acad. Sci. 2004, 1019, 111-115. [CrossRef] [PubMed] 
78. Mostoslavsky, R.; Chua, K.F.; Lombard, D.B.; Pang, W.W.; Fischer, M.R.; Gellon, L.; Liu, P.; Mostoslavsky, G.; Franco, S.; Murphy, M.M.; et al. Genomic instability and aging-like phenotype in the absence of mammalian SIRT6. Cell 2006, 124, 315-329. [CrossRef] [PubMed]

79. McCord, R.A.; Michishita, E.; Hong, T.; Berber, E.; Boxer, L.D.; Kusumoto, R.; Guan, S.; Shi, X.; Gozani, O.; Burlingame, A.L.; et al. SIRT6 stabilizes DNA-dependent protein kinase at chromatin for DNA double-strand break repair. Aging 2009, 1, 109-121. [CrossRef] [PubMed]

80. Mao, Z.; Hine, C.; Tian, X.; Van Meter, M.; Au, M.; Vaidya, A.; Seluanov, A.; Gorbunova, V. SIRT6 promotes DNA repair under stress by activating PARP1. Science 2011, 332, 1443-1446. [CrossRef] [PubMed]

81. Hayashi, M.T.; Cesare, A.J.; Fitzpatrick, J.A.; Lazzerini-Denchi, E.; Karlseder, J. A telomere-dependent DNA damage checkpoint induced by prolonged mitotic arrest. Nat. Struct. Mol. Biol. 2012, 19, 387-394. [CrossRef] [PubMed]

82. Spallarossa, P.; Altieri, P.; Aloi, C.; Garibaldi, S.; Barisione, C.; Ghigliotti, G.; Fugazza, G.; Barsotti, A.; Brunelli, C. Doxorubicin induces senescence or apoptosis in rat neonatal cardiomyocytes by regulating the expression levels of the telomere binding factors 1 and 2. Am. J. Physiol. Heart Circ. Physiol. 2009, 297, H2169-H2181. [CrossRef] [PubMed]

83. Lechel, A.; Satyanarayana, A.; Ju, Z.; Plentz, R.R.; Schaetzlein, S.; Rudolph, C.; Wilkens, L.; Wiemann, S.U.; Saretzki, G.; Malek, N.P.; et al. The cellular level of telomere dysfunction determines induction of senescence or apoptosis in vivo. EMBO Rep. 2005, 6, 275-281. [CrossRef] [PubMed]

84. Ogawa, D.; Nomiyama, T.; Nakamachi, T.; Heywood, E.B.; Stone, J.F.; Berger, J.P.; Law, R.E.; Bruemmer, D. Activation of peroxisome proliferator-activated receptor gamma suppresses telomerase activity in vascular smooth muscle cells. Circ. Res. 2006, 98, e50-e59. [CrossRef] [PubMed]

85. Minamino, T.; Mitsialis, S.A.; Kourembanas, S. Hypoxia extends the life span of vascular smooth muscle cells through telomerase activation. Mol. Cell. Biol. 2001, 21, 3336-3342. [CrossRef] [PubMed]

86. Matthews, C.; Gorenne, I.; Scott, S.; Figg, N.; Kirkpatrick, P.; Ritchie, A.; Goddard, M.; Bennett, M. Vascular smooth muscle cells undergo telomere-based senescence in human atherosclerosis: Effects of telomerase and oxidative stress. Circ. Res. 2006, 99, 156-164. [CrossRef] [PubMed]

87. Kurz, D.J.; Decary, S.; Hong, Y.; Trivier, E.; Akhmedov, A.; Erusalimsky, J.D. Chronic oxidative stress compromises telomere integrity and accelerates the onset of senescence in human endothelial cells. J. Cell Sci. 2004, 117, 2417-2426. [CrossRef] [PubMed]

88. Haendeler, J.; Hoffmann, J.; Zeiher, A.M.; Dimmeler, S. Antioxidant effects of statins via S-nitrosylation and activation of thioredoxin in endothelial cells: A novel vasculoprotective function of statins. Circulation 2004, 110, 856-861. [CrossRef] [PubMed]

89. Finkel, T.; Holbrook, N.J. Oxidants, oxidative stress and the biology of ageing. Nature 2000, 408, $239-247$. [CrossRef] [PubMed]

90. Von Zglinicki, T.; Burkle, A.; Kirkwood, T.B. Stress, DNA damage and ageing-An integrative approach. Exp. Gerontol. 2001, 36, 1049-1062. [CrossRef]

91. Kawanishi, S.; Oikawa, S. Mechanism of telomere shortening by oxidative stress. Ann. N. Y. Acad. Sci. 2004, 1019, 278-284. [CrossRef] [PubMed]

92. Griendling, K.K.; FitzGerald, G.A. Oxidative stress and cardiovascular injury: Part II: Animal and human studies. Circulation 2003, 108, 2034-2040. [CrossRef] [PubMed]

93. Xiong, W.; Mactaggart, J.; Knispel, R.; Worth, J.; Zhu, Z.; Li, Y.; Sun, Y.; Baxter, B.T.; Johanning, J. Inhibition of reactive oxygen species attenuates aneurysm formation in a murine model. Atherosclerosis 2009, 202, 128-134. [CrossRef] [PubMed]

94. Acilan, C.; Potter, D.M.; Saunders, W.S. DNA repair pathways involved in anaphase bridge formation. Genes Chromosomes Cancer 2007, 46, 522-531. [CrossRef] [PubMed]

95. Santos, J.H.; Meyer, J.N.; Skorvaga, M.; Annab, L.A.; Van Houten, B. Mitochondrial hTERT exacerbates free-radical-mediated mtDNA damage. Aging Cell 2004, 3, 399-411. [CrossRef] [PubMed]

96. Chiodi, I.; Mondello, C. Telomere-independent functions of telomerase in nuclei, cytoplasm, and mitochondria. Front. Oncol. 2012, 2, 133. [CrossRef] [PubMed]

97. Madonna, R.; De Caterina, R.; Willerson, J.T.; Geng, Y.J. Biologic function and clinical potential of telomerase and associated proteins in cardiovascular tissue repair and regeneration. Eur. Heart J. 2011, 32, 1190-1196. [CrossRef] [PubMed] 
98. Cafueri, G.; Parodi, F.; Pistorio, A.; Bertolotto, M.; Ventura, F.; Gambini, C.; Bianco, P.; Dallegri, F.; Pistoia, V.; Pezzolo, A.; et al. Endothelial and smooth muscle cells from abdominal aortic aneurysm have increased oxidative stress and telomere attrition. PLoS ONE 2012, 7, e35312. [CrossRef] [PubMed]

99. Rhee, D.B.; Ghosh, A.; Lu, J.; Bohr, V.A.; Liu, Y. Factors that influence telomeric oxidative base damage and repair by DNA glycosylase OGG1. DNA Repair 2011, 10, 34-44. [CrossRef] [PubMed]

100. Beyer, A.M.; Freed, J.K.; Durand, M.J.; Riedel, M.; Ait-Aissa, K.; Green, P.; Hockenberry, J.C.; Morgan, R.G.; Donato, A.J.; Peleg, R.; et al. Critical Role for Telomerase in the Mechanism of Flow-Mediated Dilation in the Human Microcirculation. Circ. Res. 2016, 118, 856-866. [CrossRef] [PubMed]

101. Xu, S.; Chamseddine, A.H.; Carrell, S.; Miller, F.J., Jr. Nox4 NADPH oxidase contributes to smooth muscle cell phenotypes associated with unstable atherosclerotic plaques. Redox Biol. 2014, 2, 642-650. [CrossRef] [PubMed]

102. Yudkin, J.S.; Kumari, M.; Humphries, S.E.; Mohamed-Ali, V. Inflammation, obesity, stress and coronary heart disease: Is interleukin-6 the link? Atherosclerosis 2000, 148, 209-214. [CrossRef]

103. Buchner, N.; Ale-Agha, N.; Jakob, S.; Sydlik, U.; Kunze, K.; Unfried, K.; Altschmied, J.; Haendeler, J. Unhealthy diet and ultrafine carbon black particles induce senescence and disease associated phenotypic changes. Exp. Gerontol. 2013, 48, 8-16. [CrossRef] [PubMed]

104. Tarry-Adkins, J.L.; Martin-Gronert, M.S.; Chen, J.H.; Cripps, R.L.; Ozanne, S.E. Maternal diet influences DNA damage, aortic telomere length, oxidative stress, and antioxidant defense capacity in rats. FASEB J. 2008, 22, 2037-2044. [CrossRef] [PubMed]

105. Fyhrquist, F.; Silventoinen, K.; Saijonmaa, O.; Kontula, K.; Devereux, R.B.; de Faire, U.; Os, I.; Dahlof, B. Telomere length and cardiovascular risk in hypertensive patients with left ventricular hypertrophy: The LIFE study. J. Hum. Hypertens. 2011, 25, 711-718. [CrossRef] [PubMed]

106. Demissie, S.; Levy, D.; Benjamin, E.J.; Cupples, L.A.; Gardner, J.P.; Herbert, A.; Kimura, M.; Larson, M.G.; Meigs, J.B.; Keaney, J.F.; et al. Insulin resistance, oxidative stress, hypertension, and leukocyte telomere length in men from the Framingham Heart Study. Aging Cell 2006, 5, 325-330. [CrossRef] [PubMed]

107. Perez-Rivero, G.; Ruiz-Torres, M.P.; Rivas-Elena, J.V.; Jerkic, M.; Diez-Marques, M.L.; Lopez-Novoa, J.M.; Blasco, M.A.; Rodriguez-Puyol, D. Mice deficient in telomerase activity develop hypertension because of an excess of endothelin production. Circulation 2006, 114, 309-317. [CrossRef] [PubMed]

108. Beckman, J.A.; Creager, M.A.; Libby, P. Diabetes and atherosclerosis: Epidemiology, pathophysiology, and management. JAMA 2002, 287, 2570-2581. [CrossRef] [PubMed]

109. Jacob, T.; Hingorani, A.; Ascher, E. Evidence for telomerase activation in VSMCs exposed to hyperglycemic and hyperhomocysteinemic conditions. Angiology 2009, 60, 562-568. [CrossRef] [PubMed]

110. Matsui-Hirai, H.; Hayashi, T.; Yamamoto, S.; Ina, K.; Maeda, M.; Kotani, H.; Iguchi, A.; Ignarro, L.J.; Hattori, Y. Dose-dependent modulatory effects of insulin on glucose-induced endothelial senescence in vitro and in vivo: A relationship between telomeres and nitric oxide. J. Pharmacol. Exp. Ther. 2011, 337, 591-599. [CrossRef] [PubMed]

111. Hastie, N.D.; Dempster, M.; Dunlop, M.G.; Thompson, A.M.; Green, D.K.; Allshire, R.C. Telomere reduction in human colorectal carcinoma and with ageing. Nature 1990, 346, 866-868. [CrossRef] [PubMed]

112. Balistreri, C.R.; Pisano, C.; Candore, G.; Maresi, E.; Codispoti, M.; Ruvolo, G. Focus on the unique mechanisms involved in thoracic aortic aneurysm formation in bicuspid aortic valve versus tricuspid aortic valve patients: Clinical implications of a pilot study. Eur. J. Cardiothorac. Surg. 2013, 43, e180-e186. [CrossRef] [PubMed]

113. Huusko, T.J.; Santaniemi, M.; Kakko, S.; Taskinen, P.; Ukkola, O.; Kesaniemi, Y.A.; Savolainen, M.J.; Salonurmi, T. Long telomeres in blood leukocytes are associated with a high risk of ascending aortic aneurysm. PLoS ONE 2012, 7, e50828. [CrossRef] [PubMed]

114. Wilson, W.R.; Herbert, K.E.; Mistry, Y.; Stevens, S.E.; Patel, H.R.; Hastings, R.A.; Thompson, M.M.; Williams, B. Blood leucocyte telomere DNA content predicts vascular telomere DNA content in humans with and without vascular disease. Eur. Heart J. 2008, 29, 2689-2694. [CrossRef] [PubMed]

115. Atturu, G.; Brouilette, S.; Samani, N.J.; London, N.J.; Sayers, R.D.; Bown, M.J. Short leukocyte telomere length is associated with abdominal aortic aneurysm (AAA). Eur. J. Vasc. Endovasc. Surg. 2010, 39, 559-564. [CrossRef] [PubMed]

116. Samani, N.J.; Boultby, R.; Butler, R.; Thompson, J.R.; Goodall, A.H. Telomere shortening in atherosclerosis. Lancet 2001, 358, 472-473. [CrossRef] 
117. Balistreri, C.R.; Pisano, C.; Martorana, A.; Triolo, O.F.; Lio, D.; Candore, G.; Ruvolo, G. Are the leukocyte telomere length attrition and telomerase activity alteration potential predictor biomarkers for sporadic TAA in aged individuals? Age 2014, 36, 9700. [CrossRef] [PubMed]

118. Balistreri, C.R.; Pisano, C.; Merlo, D.; Fattouch, K.; Caruso, M.; Incalcaterra, E.; Colonna-Romano, G.; Candore, G. Is the mean blood leukocyte telomere length a predictor for sporadic thoracic aortic aneurysm? Data from a preliminary study. Rejuvenation Res. 2012, 15, 170-173. [CrossRef] [PubMed]

119. Raschenberger, J.; Kollerits, B.; Ritchie, J.; Lane, B.; Kalra, P.A.; Ritz, E.; Kronenberg, F. Association of relative telomere length with progression of chronic kidney disease in two cohorts: Effect modification by smoking and diabetes. Sci. Rep. 2015, 5, 11887. [CrossRef] [PubMed]

120. LaRocca, T.J.; Seals, D.R.; Pierce, G.L. Leukocyte telomere length is preserved with aging in endurance exercise-trained adults and related to maximal aerobic capacity. Mech. Ageing Dev. 2010, 131, 165-167. [CrossRef] [PubMed]

121. Zhu, H.; Belcher, M.; van der Harst, P. Healthy aging and disease: Role for telomere biology? Clin. Sci. 2011, 120, 427-440. [CrossRef] [PubMed]

122. Tarkanyi, I.; Aradi, J. Pharmacological intervention strategies for affecting telomerase activity: Future prospects to treat cancer and degenerative disease. Biochimie 2008, 90, 156-172. [CrossRef] [PubMed]

123. Farzaneh-Far, R.; Lin, J.; Epel, E.S.; Harris, W.S.; Blackburn, E.H.; Whooley, M.A. Association of marine omega-3 fatty acid levels with telomeric aging in patients with coronary heart disease. JAMA 2010, 303, 250-257. [CrossRef] [PubMed]

124. Huang, P.; Riordan, S.M.; Heruth, D.P.; Grigoryev, D.N.; Zhang, L.Q.; Ye, S.Q. A critical role of nicotinamide phosphoribosyltransferase in human telomerase reverse transcriptase induction by resveratrol in aortic smooth muscle cells. Oncotarget 2015, 6, 10812-10824. [CrossRef] [PubMed]

125. Chen, C.; Chi, H.Y.; Yu, Z.H.; Chen, J.L. [Effects of Chinese herbal medicine Shoushen Granule on telomere length and telomerase activity of peripheral white blood cells and vascular cells in rats with atherosclerosis]. Zhong Xi Yi Jie He Xue Bao 2012, 10, 667-673. [CrossRef] [PubMed]

126. Donnini, S.; Solito, R.; Cetti, E.; Corti, F.; Giachetti, A.; Carra, S.; Beltrame, M.; Cotelli, F.; Ziche, M. Abeta peptides accelerate the senescence of endothelial cells in vitro and in vivo, impairing angiogenesis. FASEB J. 2010, 24, 2385-2395. [CrossRef] [PubMed]

127. Donnini, S.; Terzuoli, E.; Ziche, M.; Morbidelli, L. Sulfhydryl angiotensin-converting enzyme inhibitor promotes endothelial cell survival through nitric-oxide synthase, fibroblast growth factor-2, and telomerase cross-talk. J. Pharmacol. Exp. Ther. 2010, 332, 776-784. [CrossRef] [PubMed]

128. Spyridopoulos, I.; Haendeler, J.; Urbich, C.; Brummendorf, T.H.; Oh, H.; Schneider, M.D.; Zeiher, A.M.; Dimmeler, S. Statins enhance migratory capacity by upregulation of the telomere repeat-binding factor TRF2 in endothelial progenitor cells. Circulation 2004, 110, 3136-3142. [CrossRef] [PubMed]

129. Satoh, M.; Minami, Y.; Takahashi, Y.; Tabuchi, T.; Itoh, T.; Nakamura, M. Effect of intensive lipid-lowering therapy on telomere erosion in endothelial progenitor cells obtained from patients with coronary artery disease. Clin. Sci. 2009, 116, 827-835. [CrossRef] [PubMed]

130. Saliques, S.; Teyssier, J.R.; Vergely, C.; Lorgis, L.; Lorin, J.; Farnier, M.; Donzel, A.; Sicard, P.; Berchoud, J.; Lagrost, A.C.; et al. Circulating leukocyte telomere length and oxidative stress: A new target for statin therapy. Atherosclerosis 2011, 219, 753-760. [CrossRef] [PubMed]

131. Werner, C.; Gensch, C.; Poss, J.; Haendeler, J.; Bohm, M.; Laufs, U. Pioglitazone activates aortic telomerase and prevents stress-induced endothelial apoptosis. Atherosclerosis 2011, 216, 23-34. [CrossRef] [PubMed]

132. Hayashi, T.; Kotani, H.; Yamaguchi, T.; Taguchi, K.; Iida, M.; Ina, K.; Maeda, M.; Kuzuya, M.; Hattori, Y.; Ignarro, L.J. Endothelial cellular senescence is inhibited by liver $\mathrm{X}$ receptor activation with an additional mechanism for its atheroprotection in diabetes. Proc. Natl. Acad. Sci. USA 2014, 111, 1168-1173. [CrossRef] [PubMed]

(C) 2017 by the authors. Licensee MDPI, Basel, Switzerland. This article is an open access article distributed under the terms and conditions of the Creative Commons Attribution (CC BY) license (http:/ / creativecommons.org/licenses/by/4.0/). 